\title{
Bariatric surgery as a treatment for pseudotumor cerebri: case study and narrative review of the literature
}

\author{
Cirurgia bariátrica como tratamento para pseudotumor cerebri: estudo de caso e \\ revisão narrativa de literatura
}

\author{
Everton Cazzo', Martinho Antonio Gestic", Murillo Pimentel Utrini"', Felipe David Mendonça Chaimv, Fábio Henrique \\ Mendonça Chaim ${ }^{v}$, Elaine Cristina Cândidov", Luciana Bueno da Silveira Jarolavsky ${ }^{\mathrm{VII}}$, Ana Maria Neder de Almeida ${ }^{\mathrm{VIII}}$, \\ José Carlos Pareja'x, Elinton Adami Chaim ${ }^{\mathrm{x}}$
}

Department of Surgery, Faculdade de Ciências Médicas da Universidade Estadual de Campinas (FCM-UNICAMP), Campinas (SP), Brazil

'MD, MSc, PhD. Assistant Professor, Department of Surgery, Faculdade de Ciências Médicas da Universidade Estadual de Campinas (FCM-UNICAMP), Campinas (SP), Brazil. "MD, MSc. Assistant Lecturer, Department of Surgery, Faculdade de Ciências Médicas da Universidade Estadual de Campinas (FCM-UNICAMP), Campinas (SP), Brazil. "'MD. Assistant Lecturer, Department of Surgery, Faculdade de Ciências Médicas da Universidade Estadual de Campinas (FCM-UNICAMP),

Campinas (SP), Brazil.

"MD, MSc. Assistant Physician, Department of Surgery, Faculdade de Ciências Médicas da Universidade Estadual de Campinas (FCM-UNICAMP), Campinas (SP), Brazil. ${ }^{\vee}$ MD. Resident Physician, Department of Surgery, Faculdade de Ciências Médicas da Universidade Estadual de Campinas (FCM-UNICAMP), Campinas (SP), Brazil.

"BSC, MSc. Assistant Nurse, Bariatric Surgery Outpatient Clinic, Hospital de Clínicas da Universidade Estadual de Campinas (HC-UNICAMP), Campinas (SP), Brazil.

"n'BSc. Head Nurse, Bariatric Surgery Outpatient Clinic, Hospital de Clínicas da Universidade Estadual de Campinas (HC-UNICAMP), Campinas (SP), Brazil. VIIIBSC. Attending Psychologist, Bariatric Surgery Outpatient Clinic, Hospital de Clínicas da Universidade Estadual de Campinas (HC-UNICAMP), Campinas (SP), Brazil. ${ }^{1 \times} M D$, PhD. Associate Professor, Department of Surgery, Faculdade de Ciências Médicas da Universidade Estadual de Campinas (FCM-UNICAMP), Campinas (SP), Brazil. ${ }^{x} M D, M S c$, PhD. Full Professor. Department of Surgery, Faculdade de Ciências Médicas da Universidade Estadual de Campinas (FCM-UNICAMP), Campinas (SP), Brazil.

\section{KEY WORDS:}

Pseudotumor cerebri.

Obesity.

Bariatric surgery.

Gastric bypass.

Intracranial hypertension.

\section{PALAVRAS-CHAVE:}

Pseudotumor cerebral.

Obesidade.

Cirurgia bariátrica.

Derivação gástrica.

Hipertensão intracraniana.

\section{ABSTRACT}

CONTEXT: Pseudotumor cerebri occurs when there is an increase in intracranial pressure without an underlying cause, usually leading to loss of vision. It is most commonly observed in obese women of childbearing age.

CASE REPORT: A 46-year-old woman presented at our service with idiopathic intracranial hypertension that had been diagnosed two years earlier, which had led to chronic refractory headache and an estimated $30 \%$ loss of visual acuity, associated with bilateral papilledema. She presented partial improvement of the headache with acetazolamide, but the visual loss persisted. Her intracranial pressure was $34 \mathrm{cmH}_{2} \mathrm{O}$. She presented a body mass index of $39.5 \mathrm{~kg} / \mathrm{m}^{2}$, also associated with high blood pressure. Computed tomography of the cranium with endovenous contrast did not show any abnormalities. She underwent Roux-en-Y gastric bypass with uneventful postoperative evolution. One month following surgery, she presented a $24 \%$ excess weight loss. An ophthalmological examination revealed absence of visual loss and remission of the papilledema. There were no new episodes of headache following the surgery. There was also complete resolution of high blood pressure. The intracranial pressure decreased to $24 \mathrm{cmH}_{2} \mathrm{O}$, six months after the surgery.

CONCLUSION: Although the condition is usually associated with obesity, there are few reports of bariatric surgery among individuals with pseudotumor cerebri. In cases studied previously, there was high prevalence of resolution or improvement of the disease following bariatric surgery. There is no consensus regarding which technique is preferable. Thus, further research is necessary in order to establish a specific algorithm.

\section{RESUMO}

CONTEXTO: O pseudotumor cerebri ocorre quando há aumento na pressão intracraniana sem causa subjacente, comumente levando a perda visual. É mais comum em mulheres obesas em idade fértil.

RELATO DE CASO: Mulher de 46 anos, foi admitida com hipertensão intracraniana idiopática diagnosticada há dois anos, que levou a cefaleia refratária crônica e perda estimada de $30 \%$ da acuidade visual, associada a papiledema bilateral. Apresentou melhora parcial da cefaleia com acetazolamida, mas a perda visual persistiu. A pressão intracraniana era de $34 \mathrm{cmH}_{2} \mathrm{O}$. Apresentava índice de massa corpórea de 39,5 $\mathrm{kg} / \mathrm{m}^{2}$, associado a hipertensão arterial. Tomografia computadorizada com contraste endovenoso de crânio não apresentou anormalidades. Foi submetida ao bypass gástrico em Y de Roux, com evolução pósoperatória sem intercorrências. Um mês após a cirurgia, apresentou perda de peso em excesso de 24\%. Um exame oftalmológico demonstrou ausência de perda visual e remissão do papiledema; não houve novos episódios de cefaleia após a cirurgia. Houve também resolução completa da hipertensão arterial. A pressão intracraniana caiu para $24 \mathrm{cmH}_{2} \mathrm{O}$ após seis meses da cirurgia.

CONCLUSÃO: Embora a condição seja usualmente associada à obesidade, há escassos relatos de cirurgia bariátrica em indivíduos com pseudotumor cerebri. Nos casos previamente estudados, há alta prevalência de resolução ou de melhora da doença após a cirurgia bariátrica. Não há consenso sobre qual é a técnica cirúrgica de escolha. Portanto, mais estudos são necessários para estabelecer um algoritmo específico. 


\section{INTRODUCTION}

Pseudotumor cerebri (PC), also known as benign or idiopathic intracranial hypertension (IIH), is a disorder of elevated intracranial pressure (ICP) that primarily affects obese women of childbearing age, but can also affect non-obese adults and children. ${ }^{1,2}$ IIH occurs predominantly in women, especially in the age range from 20 to 45 , who are four to eight times more likely than men to be affected. ${ }^{1,2}$ The incidence is approximately $2 / 100,000$ and, given the global obesity epidemic, is likely to rise further. ${ }^{3}$ According to the Dandy criteria, as revised by Friedman and Jacobson, IIH is diagnosed when six criteria are fulfilled:

1. suggestive symptoms or cranial hypertension are present;

2. suggestive signs of cranial hypertension are present;

3. normal cerebrospinal fluid composition;

4. elevation of lumbar puncture opening pressure $\left(>20 \mathrm{cmH}_{2} \mathrm{O}\right.$ in lean and $>25 \mathrm{cmH}_{2} \mathrm{O}$ in obese individuals);

5. no abnormalities on computed tomography or magnetic resonance scans; and

6. no other identifiable cause of intracranial pressure.

Papilledema is typically present..$^{2-5}$ The underlying pathophysiological mechanisms that lead to this disease remain unknown, and the best-accepted theories are that the change in cranial pressure is linked to increased abdominal pressure, hormonal changes and unrecognized disorders in the cerebral venous system and in relation to cerebrospinal fluid resorption. ${ }^{4,5}$

Headache is the most common symptom of $\mathrm{PC}$ and is present in over $90 \%$ of these patients. ${ }^{6} \mathrm{Up}$ to $86 \%$ develop some degree of visual impairment, which may be severe and even blinding in $10 \%{ }^{7}$

\section{CASE REPORT}

A 46-year-old woman presented at our service with previously diagnosed IIH that had been diagnosed two years earlier, which had led to chronic refractory headache and an estimated $30 \%$ loss of visual acuity, associated with bilateral papilledema. She presented partial improvement of the headache with acetazolamide, but the visual loss persisted. The intracranial pressure, measured by means of lumbar puncture, was $34 \mathrm{cmH}_{2} \mathrm{O}$. Biochemical, cytological and microbiological assessments on the cerebrospinal fluid did not reveal any abnormalities. Contrast-enhanced computed tomography did not show any abnormalities either (Figure 1a). She has been obese for 20 years and, on admission, presented a body mass index (BMI) of $39.5 \mathrm{~kg} / \mathrm{m}^{2}$, also associated with high blood pressure that was controlled through use of enalapril maleate.

She underwent Roux-en-Y gastric bypass with uneventful postoperative evolution. One month after surgery, the patient reported a slight reduction in the frequency of her episodes of headache and improvement of her visual impairment; there was also complete resolution of her high blood pressure. She had lost $24 \%$ of her excess weight by then. Use of acetazolamide and enalapril maleate was discontinued at this point.

Six months after the surgery, she presented a $55 \%$ loss of excess weight, such that her BMI was $31.5 \mathrm{~kg} / \mathrm{m}^{2}$. An ophthalmological examination revealed absence of visual loss and remission of the papilledema. The patient reported that there had been a more significant reduction in the frequency and intensity of the episodes of headache since her previous postoperative report. Lumbar puncture was performed again and the opening pressure was found to have decreased to $24 \mathrm{cmH}_{2} \mathrm{O}$. There were no abnormalities in the biochemical, cytological and microbiological assessments on cerebrospinal fluid. Table 1 details the characteristics of the cerebrospinal fluid before and six months after surgery. Contrastenhanced computed tomography showed that no abnormalities were present (Figure 1b).

\section{DISCUSSION}

There are several treatment options for IIH. They may aim towards providing headache prophylaxis through using propranolol, amitriptyline and topiramate, or towards alleviation of intracranial pressure and optic symptoms through using diuretics such as acetazolamide and furosemide. In refractory

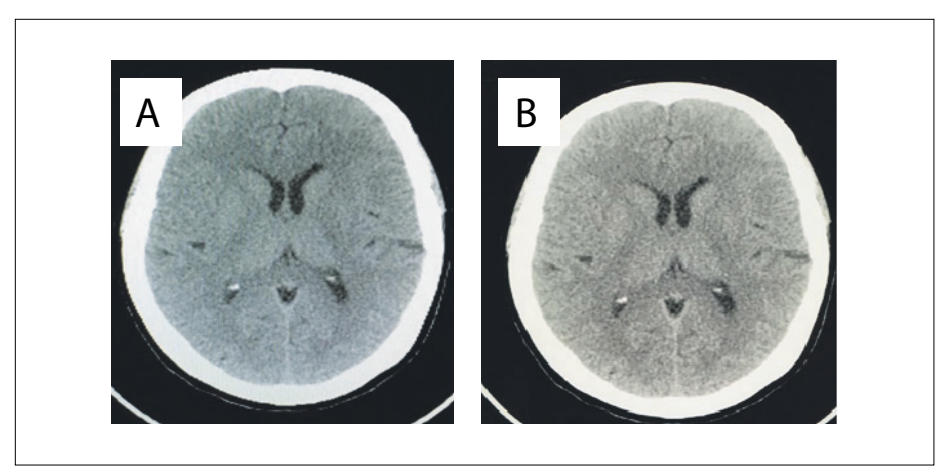

Figure 1. Computed tomography scans: 1A) preoperative; 1B) postoperative.

Table 1. General cerebrospinal fluid characteristics before and after surgery in a patient with pseudotumor cerebri who underwent bariatric surgery

\begin{tabular}{lcc} 
& Preoperative & Postoperative \\
Protein $(\mathrm{mg} / \mathrm{dl})$ & 26 & 23 \\
Glucose $(\mathrm{mg} / \mathrm{dl})$ & 62 & 55 \\
$\mathrm{pH}$ & 7.3 & 7.31 \\
Red blood cells $\left(\mathrm{cells} / \mathrm{mm}^{3}\right)$ & 0 & 0 \\
White blood cells $\left(\mathrm{cells} / \mathrm{mm}^{3}\right)$ & 2 & 1 \\
Gram stain & Negative & Negative \\
Culture & Negative & Negative \\
\hline
\end{tabular}


cases, use of corticosteroids may be warranted. There is also the possibility of surgical interventions that aim to decrease the intracranial pressure (through lumbar or ventriculoperitoneal shunts) or alleviate the visual damage (through optic nerve sheath fenestration). The outcomes previously reported from these surgical procedures have been mixed and somewhat frustrating. ${ }^{1-4,5-7}$

Although usually associated with obesity, there are few reports of bariatric surgery among individuals with PC. A review of the literature was conducted through an online search for the MeSH terms "pseudotumor cerebri" and "bariatric surgery" in MEDLINE (via PubMed) and LILACS (via BVS) (Table 2).

There was significant overlap between the databases. After careful analysis, we selected three systematic reviews, one retrospective cohort study, two case series and nine case reports that evaluated bariatric surgery in individuals with $\mathrm{PC}$, or that compared bariatric surgery with other treatment regimens. Table $3^{8-22}$ summarizes the main articles selected and their respective levels of evidence according to the Oxford classification, and the results observed. Figure 2 is a flow diagram showing the literature search and selection of articles.

Although two systematic reviews ${ }^{10,13}$ were found, the majority of the studies that evaluated bariatric surgery as a treatment for IIH were case reports and case series. Thus, the quality of most of the evidence available so far is poor. The present report is only the second published case on pseudotumor cerebri that was treated by means of bariatric surgery in Brazil. The first case was reported by Fontes et al., ${ }^{21}$ who observed that complete resolution of PC-related symptoms was achieved in a 37-yearold female after RYGB. Nadkarni et al. ${ }^{20}$ reported on two cases of obese women, both aged 42 years, who underwent gastric bypass and gastric stapling. Complete resolution of PC was observed at the one-year reevaluation. Soto et al. ${ }^{18}$ described the case of a 30-year-old woman who presented complete resolution of headache, visual impairment and dizziness three months after undergoing laparoscopic RYGB. Levin et al. ${ }^{11}$ reported the case of a 29-year-old obese woman with PC who presented dramatic improvement of headache four months after laparoscopic RYGB, and maintained this improvement one year after surgery. The case reported in our study also presented early improvement in PC-related symptoms, similar to the previously published evidence.

Roth et al. ${ }^{9}$ compared individuals who underwent ventricular shunt surgery alone or in association with bariatric surgery. Their study revealed that, among shunted patients, bariatric surgery might not lead to resolution of PC-related symptoms and that these patients might remain shunt-dependent.

The systematic review conducted by Fridley et al. ${ }^{13}$ identified a total of 62 individuals with PC who underwent bariatric surgery. They observed that the resolution rate for PC-related symptoms following bariatric surgery was $92 \%$, with an average postoperative pressure decrease of $25.4 \mathrm{cmH}_{2} \mathrm{O}$. These authors concluded that the class IV evidence published up to the time of their study suggested that bariatric surgery might be an effective treatment for PC among obese patients, but that prospective, controlled studies would be necessary for better elucidation of its role. A more recent systematic review by Handley et al., ${ }^{10}$ which enrolled 65 individuals, showed that there was an overall improvement in PC symptoms after bariatric surgery, in 60 of the 65 patients observed (92\%). The postoperative lumbar puncture opening pressure was shown to decrease by an average of $189 \mathrm{mmH}_{2} \mathrm{O}$ in the patients for whom records of this pressure were available. A comprehensive systematic review conducted by Kalyvas et al., ${ }^{8}$ which also included studies that evaluated other treatment options, evaluated 32 individuals who underwent bariatric surgery. They observed that papilledema resolved in all patients and that headache improvement was documented in $96 \%$ of the patients, with no deterioration in any of the patients. However, these authors also emphasized that there was a higher degree of morbidity in the bariatric surgery group, compared with the other treatment regimens evaluated in other studies.

Despite the growing evidence of high rates of improvement and even resolution of $\mathrm{PC}$ achieved by means of bariatric surgery, the low quality of most of the available evidence means that no ultimate conclusions can be reached. Nonetheless, there is an increasing perception that obese individuals with increased

Table 2. Database search results for bariatric surgery among individuals with pseudotumor cerebri, on November 19,2016

\begin{tabular}{|c|c|c|}
\hline Electronic databases & Search strategies & Results \\
\hline MEDLINE (PubMed) & ((Pseudotumor cerebri) OR (Intracranial hypertension)) AND (Bariatric surgery) & $\begin{array}{l}3 \text { systematic reviews } \\
1 \text { retrospective cohort study } \\
2 \text { case series } \\
8 \text { case reports }\end{array}$ \\
\hline LILACS (BVS) & $\begin{array}{c}\text { (((Pseudotumor cerebri) OR (Pseudotumor cerebral) OR (Seudotumor cerebral)) OR } \\
\text { ((Intracranial hypertension) OR (Hipertensão Intracraniana) OR (Hipertensión Intracraneal))) } \\
\text { AND ((Bariatric surgery) OR (Cirugia Bariátrica) OR (Cirurgia Bariátrica)) }\end{array}$ & $\begin{array}{l}2 \text { systematic reviews } \\
1 \text { retrospective cohort study } \\
1 \text { case series } \\
4 \text { case reports }\end{array}$ \\
\hline
\end{tabular}


Table 3. Main studies on bariatric surgery among individuals with pseudotumor cerebri

Study Methods N $\quad \begin{gathered}\text { Level of } \\ \text { evidence }\end{gathered} \quad$ Treatment option

Systematic review
Kalyvas et al. $\quad 728$

13

$\begin{array}{ll}\text { Roth et } \text { al. }^{9} \quad \text { Case series } & \text { (6: shunting and } \\ & \text { bariatric surgery; } \\ & \text { 7: only shunting) }\end{array}$

Handley et al. ${ }^{10} \quad$ Systematic review

65

$3 a$

4

341: optic nerve sheath fenestration

128: lumboperitoneal shunting

72: ventriculoperitoneal shunting

155: venous sinus stenting

32: bariatric surgery (29: gastric

bypass; 2 : gastroplasty; 1 : gastric banding)

Bariatric surgery in individuals who previously underwent shunting procedures vs. only shunting

(4: sleeve gastrectomy; 2 : gastric banding)

Bariatric surgery (48: gastric bypass; 6: gastric banding; 4: gastroplasty; 5 : sleeve gastrectomy)
The studies were heterogeneous. No type of surgery proved to be clearly superior. Bariatric surgery presented a higher success rate among obese individuals but also a higher morbidity rate.

Bariatric surgery is less effective and may lead to over-drainage symptoms in individuals who previously underwent shunting

Overall improvement in $92 \%$ of the individuals; mean $18.9 \mathrm{cmH}_{2} \mathrm{O}$ decrease in lumbar puncture pressure

Improvement of headache and reversal of papilledema

Total resolution or significant improvement of headache (mean improvement in pain score of 76.3/100 (range 55-95) on an analogue pain scale)

Resolution of headache in $92 \%$ of the individuals; mean $25.4 \mathrm{cmH}_{2} \mathrm{O}$ decrease in CSF pressure

Complete resolution of headache and visual loss

Complete resolution of headache and CSF rhinorrhea

Complete resolution of visual loss

Complete resolution of visual loss

Complete resolution of headache, visual loss and dizziness

Complete resolution of headache and visual loss

Complete resolution of headache and visual loss

Complete resolution of headache and visual loss

Resolution of visual loss in 100\% and headache and tinnitus in $94.7 \%$ of the individuals

\begin{tabular}{|c|c|c|c|c|}
\hline Sugerman et al. ${ }^{22}$ & $\begin{array}{c}\text { Retrospective } \\
\text { cohort }\end{array}$ & 24 & $2 b$ & $\begin{array}{l}\text { 23: gastric bypass } \\
\text { 1: gastric banding }\end{array}$ \\
\hline
\end{tabular}

$\mathrm{N}=$ number of individuals; CSF = cerebrospinal fluid. Levels of evidence according to the Oxford classification - 1a = Systematic reviews (with homogeneity) of randomized controlled trials; $1 \mathrm{~b}=$ Individual randomized controlled trials (with narrow confidence interval); $1 \mathrm{c}=:$ "All or none" randomized controlled trials; $2 \mathrm{a}=$ Systematic reviews (with homogeneity) of cohort studies; $2 \mathrm{~b}=$ Individual cohort study or low-quality randomized controlled trials (e.g. < 80\% follow-up); 2c = "Outcomes" research; ecological studies; 3a = Systematic review (with homogeneity) of case-control studies;

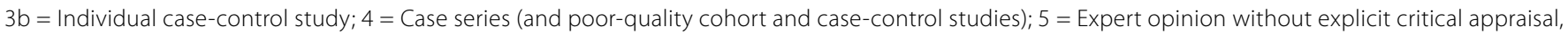
or based on physiology, bench research or "first principles". 


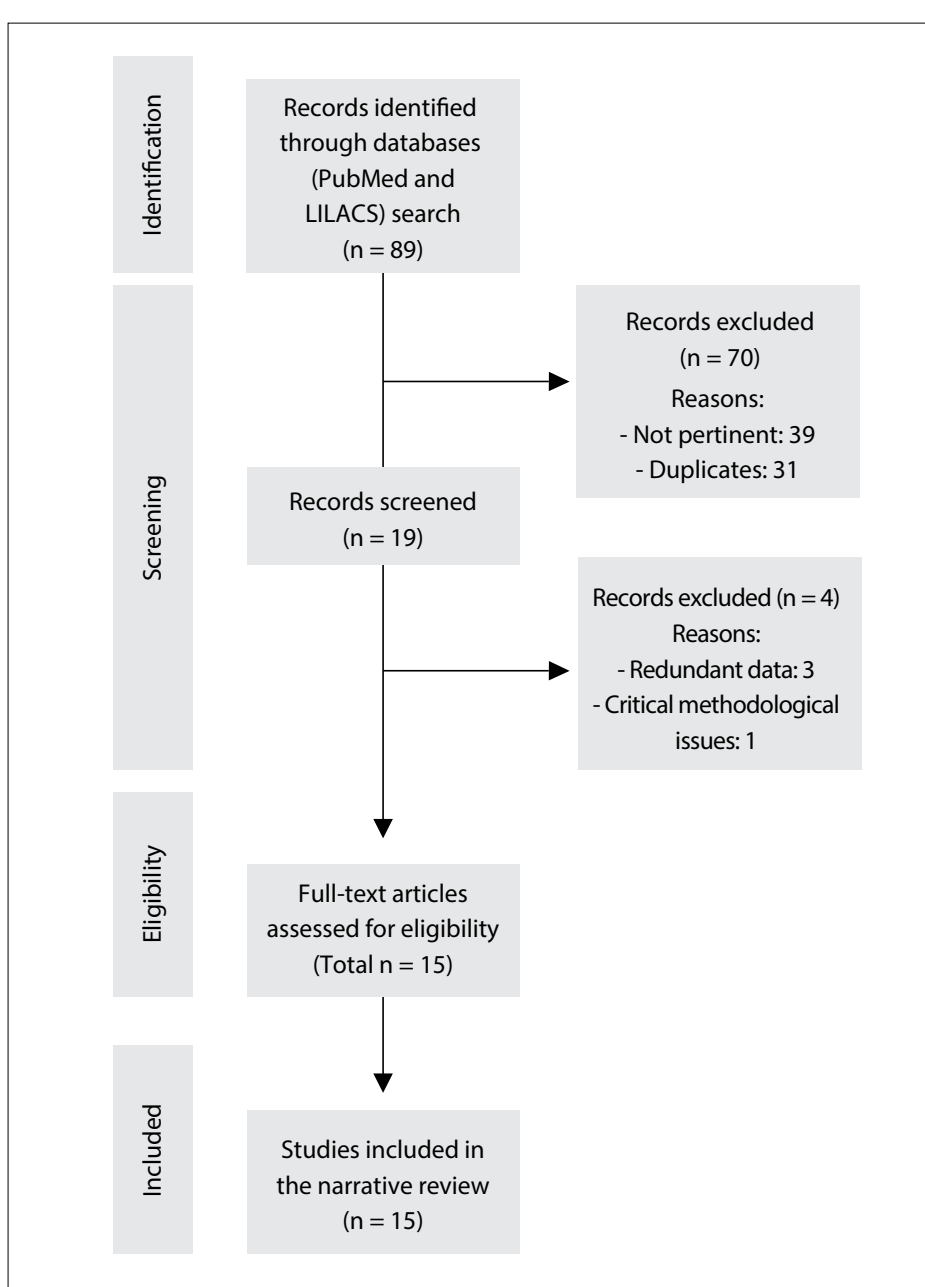

Figure 2. Flow diagram of the narrative review of the literature.

intracranial hypertension may significantly benefit from bariatric surgery. Hence, individuals who fulfill the current indications for bariatric surgery should at least be offered this type of treatment.

\section{CONCLUSION}

Bariatric surgery led to early improvement in the PC-related symptoms in this report, and this was comparable with evidence published previously.

\section{REFERENCES}

1. Corbett JJ, Savino PJ, Thompson HS, et al. Visual loss in pseudotumor cerebri. Follow-up of 57 patients from five to 41 years and a profile of 14 patients with permanent severe visual loss. Arch Neurol. 1982;39(8):461-74.

2. Hainline C, Rucker JC, Balcer LJ. Current concepts in pseudotumor cerebri. Curr Opin Neurol. 2016;29(1):84-93.

3. Wakerley BR, Tan MH, Ting EY. Idiopathic intracranial hypertension. Cephalalgia. 2015;35(3):248-61.

4. Kesler A, Stolovic N, Bluednikov Y, Shohat T. The incidence of idiopathic intracranial hypertension in Israel from 2005 to 2007: results of a nationwide survey. Eur J Neurol. 2014;21 (8):1055-9.
5. Friedman DI, Liu GT, Digre KB. Revised diagnostic criteria for the pseudotumor cerebri syndrome in adults and children. Neurology. 2013;81(13):1159-65.

6. Mallery RM, Friedman DI, Liu GT. Headache and the pseudotumor cerebri syndrome. Curr Pain Headache Rep. 2014;18(9):446.

7. OCT Sub-Study Committee for NORDIC Idiopathic Intracranial Hypertension Study Group, Auinger P, Durbin M, et al. Baseline OCT measurements in the idiopathic intracranial hypertension treatment trial, part I: quality control, comparisons, and variability. Invest Ophthalmol Vis Sci. 2014;55(12):8180-8.

8. Kalyvas AV, Hughes M, Koutsarnakis C, et al. Efficacy, complications and cost of surgical interventions for idiopathic intracranial hypertension: a systematic review of the literature. Acta Neurochir (Wien). 2017;159(1):33-49.

9. Roth J, Constantini S, Kesler A. Over-drainage and persistent shuntdependency in patients with idiopathic intracranial hypertension treated with shunts and bariatric surgery. Surg Neurol Int. 2015;6(Suppl 27):S655-60.

10. Handley JD, Baruah BP, Williams DM, et al. Bariatric surgery as a treatment for idiopathic intracranial hypertension: a systematic review. Surg Obes Relat Dis. 2015;11(6):1396-403.

11. Levin AA, Hess D, Hohler AD. Treatment of idiopathic intracranial hypertension with gastric bypass surgery. Int J Neurosci. 2015;125(1):78-80.

12. Egan RJ, Meredith HE, Coulston JE, et al. The effects of laparoscopic adjustable gastric banding on idiopathic intracranial hypertension. Obes Surg. 2011;21(2):161-6

13. Fridley J, Foroozan R, Sherman V, Brandt ML, Yoshor D. Bariatric surgery for the treatment of idiopathic intracranial hypertension. J Neurosurg. 2011;114(1):34-9.

14. Williams A, Morgan J, Johnson A, et al. Resolution of Pseudotumor Cerebri following surgery for morbid obesity. J Surg Case Rep. 2010;2010(6):7.

15. Stangherlin P, Ledeghen S, Scordidis V, Rubay R. Benign intracranial hypertension with recurrent spontaneous cerebrospinal fluid rhinorrhoea treated by laparoscopic gastric banding. Acta Chir Belg. 2008;108(5):616-8.

16. Leslie DB, Kellogg TA, Boutelle KN, et al. Preserved vision without growth retardation after laparoscopic Roux-en-Y gastric bypass in a morbidly obese child with pseudotumor cerebri: 36-month follow-up. J Pediatr Surg. 2008;43(7):e27-30.

17. Chandra V, Dutta S, Albanese CT, et al. Clinical resolution of severely symptomatic pseudotumor cerebri after gastric bypass in an adolescent. Surg Obes Relat Dis. 2007;3(2):198-200.

18. Soto FC, Antozzi P, Szomstein S, et, al. Indication for emergent gastric bypass in a patient with severe idiopathic intracranial hypertension: case report and review of the literature. Surg Obes Relat Dis. 2005;1 (5):503-5.

19. Lazcano-Herrera EE, Romero-Hernández T, Martínez-Ordaz JL, BlancoBenavides R. Tratamiento del pseudotumor cerebri con cirugia bariátrica. Reporte de un caso. Cirugia y Cirujanos. 2005;73(5):375-8. Available from: http://www.medigraphic.com/pdfs/circir/cc-2005/cc055i.pdf. Accessed in 2017 (Feb 6). 
20. Nadkarni T, Rekate HL, Wallace D. Resolution of pseudotumor cerebri after bariatric surgery for related obesity. Case report. J Neurosurg. 2004;101(5):878-80.

21. Fontes D, Sanches MD, Nascimento SZ, et al. Cirurgia bariátrica no tratamento do pseudotumor cerebral: relato de caso [Bariatric surgery for treatment of pseudotumor cerebro: a case report]. Rev Méd Minas Gerais. 2003;13(4):292-3.

22. Sugerman HJ, Felton WL 3rd, Sismanis A, et al. Gastric surgery for pseudotumor cerebri associated with severe obesity. Ann Surg. 1999;229(5):634-40; discussion 640-2.

Sources of funding: None

Conflict of interest: None

Date of first submission: November 19, 2016

Last received: January 5, 2017

Accepted: January 6, 2017

\section{Address for correspondence:}

Everton Cazzo

Departamento de Cirurgia da Facudade de Ciências Médicas da Universidade Estadual de Campinas (FCM-UNICAMP)

Rua Alexander Fleming, s/no

Cidade Universitaria Zeferino Vaz - Campinas (SP) - Brasil

CEP 13085-000

E-mail:notrevezzo@yahoo.com.br 